\title{
Genomic Analysis of Different Chlorobium Strains by Pulsed- Field Gel Electrophoresis and Ribotyping
}

\author{
SEBASTIÁN MÉNDEZ-ALVAREZ, ${ }^{1 *}$ ISABEL ESTEVE, ${ }^{1}$ RICARDO GUERRERO ${ }^{2}$ AND NÚRIA GAJU ${ }^{1}$ \\ Institut de Biologia Fonamental and Departament de Genètica i Microbiologia, Universitat Autònoma de Barcelona, \\ 08193 Bellaterra, ${ }^{1}$ and Departament de Microbiologia, Universitat de Barcelona, 08028 Barcelona, ${ }^{2}$ Spain
}

\begin{abstract}
Pulsed-field gel electrophoresis was used to characterize the genomes of 15 Chlorobium strains. An analysis of chromosomal macrorestriction patterns allowed us to determine the chromosome sizes, which ranged from 1,435 to $3,342 \mathrm{~kb}$ depending on the strain. Moreover, this analysis revealed that, even though the genus Chlorobium is a phylogenetically coherent taxon, there is a great deal of genomic heterogeneity within it. This heterogeneity was corroborated by performing a ribotyping analysis, which showed that the rRNA hybridization patterns of most strains are unique.
\end{abstract}

The green sulfur bacteria are anaerobic, photolithotrophic organisms that require light as an energy source and suitable electron donors, such as hydrogen sulfide or elemental sulfur (11). They are commonly found in anaerobic zones of karsticsulfated lakes and in very thin layers of stratified microbial communities (4). The genus Chlorobium, which includes six species, is the most representative taxon of this group of bacteria. The different Chlorobium species are distinguished on the basis of their morphological, biochemical, and ultrastructural properties (10). Consequently, the genus is heterogeneous genetically since the $\mathrm{G}+\mathrm{C}$ contents of the species range from 49 to $58.1 \mathrm{~mol} \%$. Moreover, comparisons of $16 \mathrm{~S}$ rRNAs have been performed with only some strains of this genus (3). The heterogeneity of the genus has been recently demonstrated with the species Chlorobium limicola (8), in which we described chromosomic and plasmidic differences between strains. Thus, a genotypically determined classification of Chlorobium strains, both above and below the species level, is needed. Nucleic acid studies should provide greater objectivity and a unifying taxonomic concept based on genetic relatedness. Nevertheless, even though genetic techniques have been developed in the last few years $(1,5,7,21)$, genomic analysis of the green sulfur bacteria has been carried out only with the species C. limicola (9) and Chlorobium tepidum (10).

According to many studies, pulsed-field gel electrophoresis (PFGE) is an especially useful technique for analyzing bacterial genomes. Moreover, combining PFGE with restriction enzymes that cut bacterial chromosomes infrequently makes it possible to obtain chromosome restriction patterns that provide a trustworthy fingerprint of each microorganism. Comparative analysis of these patterns makes it feasible to detect the genomic heterogeneity within a group of microorganisms (14). On the other hand, other molecular techniques, such as ribotyping, are currently available for strain typing, and these techniques can be used to confirm the results derived from analyses of chromosomal restriction patterns obtained by PFGE (9). These two approaches were used in this study to analyze the genetic heterogeneity of 15 Chlorobium strains belonging to five species.

Materials. The bacterial strains studied are listed in Table 1. New isolates were identified on the basis of their biochemical, morphological, and ultrastructural properties $(11,12)$. Chlorobium chlorovibrioides UdG6026 and C. limicola UdG6038,

\footnotetext{
* Corresponding author. Phone: 34-3-5811278. Fax: 34-3-5812011.
} Electronic mail address: ibfn0@cc.uab.es.
UdG6041, and UdG6042 were characterized at the Department of Microbiology, University of Girona, Girona, Spain (13). Most cultures were grown photolitoautotrophically in rubber-capped bottles at $25^{\circ} \mathrm{C}$ with 50 microeinsteins of continuous illumination $\cdot \mathrm{m}^{-2} \cdot \mathrm{s}^{-1}$. C. tepidum $\mathrm{TLS}^{\mathrm{T}}(\mathrm{T}=$ type strain) was grown at $45^{\circ} \mathrm{C}(22)$. Cultures were grown in Pfennig minimal medium at $\mathrm{pH} 6.6$ to 6.9 (20) to concentrations of about $10^{8}$ cells per ml.

DNA preparation and restriction enzyme digestion for PFGE. Intact genomic DNAs were prepared in agarose plugs as described by Smith and Cantor (18). Restriction assays were carried out as described previously $(6,15)$. Restriction enzymes and DNA standards were purchased from New England Biolabs, Beverly, Mass., and Boehringer Mannheim, Mannheim, Germany.

PFGE. PFGE $(17,19)$ was performed in an apparatus obtained from Pharmacia-LKB, Uppsala, Sweden. Gels were made of $1 \%$ agarose (SeaKem LE Agarose; FMC, Rockland, Maine) and were electrophoresed at $15^{\circ} \mathrm{C}$ in modified TBE buffer (100 mM Tris, $100 \mathrm{mM}$ boric acid, $0.2 \mathrm{mM}$ EDTA; final pH 8 to 8.4 ).

Ribotyping. Heterologous rRNA probes from Escherichia coli were used for ribotyping. DNA extraction, digestion, and hybridization for ribotyping were performed as described in the Technical Handbook of Acetylaminofuorene Ribosomal $R N A$ (Eurogentec, Seraing, Belgium).

For ribotyping, EcoRI DNA fragments were separated by low-voltage $\left(1.5 \mathrm{~V} \cdot \mathrm{cm}^{-1}\right)$ electrophoresis overnight on $0.5 \%$ agarose gels in $1 \times$ TAE buffer. Digoxigenin-labeled Citrobacter sp. strain 32 DNA digested with MluI was used as the size marker.

Plasmid analysis. Plasmids smaller than $50 \mathrm{~kb}$ were detected by conventional electrophoresis. DNA isolated by the alkaline method (15) was electrophoresed through a $0.7 \%$ agarose gel for $6 \mathrm{~h}$ with a constant electric field of $5 \mathrm{~V} \cdot \mathrm{cm}^{-1}$. Different Chlorobium strains contained different plasmids smaller than $50 \mathrm{~kb}$ (Table 1). Interestingly, the previously reported $14-\mathrm{kb}$ plasmid which confers the ability to utilize thiosulfate and had been detected in C. limicola f. sp. thiosulfatophilum DSM 249 and $C$. limicola $\mathrm{f}$. sp. thiosulfatophilum BF8000 was detected in C. limicola f. sp. thiosulfatophilum UdG6042. The presence of plasmids larger than $50 \mathrm{~kb}$ was studied by using samples subjected to PFGE at a field strength of $10 \mathrm{~V} \cdot \mathrm{cm}^{-1}$ and different pulse times (100 to $150 \mathrm{~s}$ ) without restriction cleavage. Large extrachromomsomal elements were detected in $C$. limicola DSM $245^{\mathrm{T}}$, C. limicola f. sp. thiosulfatophilum DSM 249, $\mathrm{BF} 8000$, and $\mathrm{UdG6038}$, and C. vibrioforme f. sp. thiosulfatophi- 
TABLE 1. Bacterial strains

\begin{tabular}{|c|c|c|c|c|}
\hline Strain & Source $^{a}$ & $\begin{array}{l}\text { Thiosulfate } \\
\text { utilization }\end{array}$ & $\begin{array}{l}\mathrm{G}+\mathrm{C} \text { content } \\
\quad(\mathrm{mol} \%)\end{array}$ & $\begin{array}{l}\text { Presence of plasmids smaller } \\
\text { than } 50 \mathrm{~kb} \text { (size) }\end{array}$ \\
\hline C. limicola DSM $245^{\mathrm{T}}$ & DSM & $--^{b}$ & 51.0 & - \\
\hline C. limicola $\mathrm{f}$. sp. thiosulfatophilum DSM 249 & DSM & + & 58.1 & $+(14 \mathrm{~kb})$ \\
\hline C. limicola $\mathrm{BF} 8000^{c}$ & UAB & + & $\mathrm{ND}^{d}$ & $+(14 \mathrm{~kb})$ \\
\hline C. limicola $\mathrm{BF} 8010^{c}$ & UAB & - & ND & - \\
\hline C. limicola UdG6038 & UdG & + & 56.4 & $+(\mathrm{ND})$ \\
\hline C. limicola UdG6041e & UdG & - & ND & - \\
\hline C. limicola $\mathrm{UdG} 6042^{e}$ & UdG & + & ND & $+(14 \mathrm{~kb})$ \\
\hline C. phaeobacteroides DSM $266^{\mathrm{T}}$ & DSM & - & 49.0 & - \\
\hline C. phaeobacteroides $\mathrm{BF} 8600^{i}$ & $\mathrm{UAB}$ & - & ND & - \\
\hline C. phaeobacteroides $\mathrm{BF} 8610^{\circ}$ & UAB & - & ND & - \\
\hline C. vibrioforme f. sp. thiosulfatophilum DSM 263 & $\mathrm{UAB}$ & + & 53.5 & $+(\mathrm{ND})$ \\
\hline C. vibrioforme $\mathrm{BF} 8200^{f}$ & UAB & + & ND & $+(\mathrm{ND})$ \\
\hline C. vibrioforme $\mathrm{BF} 8210^{g}$ & $\mathrm{UAB}$ & - & ND & - \\
\hline C. chlorovibrioides UdG6026 ${ }^{e}$ & UdG & - & ND & - \\
\hline C. tepidum TLS $^{\mathrm{Th}}$ & $\mathrm{UAB}$ & + & 56.5 & $+(\mathrm{ND})$ \\
\hline
\end{tabular}

${ }^{a}$ DSM, Deutsche Sammlung von Mikroorganismen und Zellkulturen; UAB, Universitat Autònoma de Barcelona; UdG, Universitat de Girona.

${ }^{b}-$, negative; + , positive.

${ }^{c}$ Strain isolated by $\mathrm{M}$. Algueró, Universitat Autònoma de Barcelona.

${ }^{d}$ ND, not determined.

e Strain isolated by Imma Pibernat, Universitat de Girona.

${ }^{f}$ Strain isolated by Balbina Nogales, Universitat Autònoma de Barcelona.

$g$ Strain isolated by Sebastián Méndez-Alvarez, Universitat Autònoma de Barcelona.

${ }^{h}$ Strain provided by Michael Madigan, Southern Illinois University, Carbondale.

lum DSM 263 and BF8200. The sizes of these large extrachromosomal elements were not estimated.

Chromosome restriction patterns. To analyze the restriction patterns of the chromosomes from different Chlorobium strains, the following restriction endonucleases were tested: AseI, BclI, DraI, EcoRV, PacI, SfiI, and SwaI. We decided to utilize two of these restriction endonucleases, PacI (data not shown) and $S w a I$, because they provided the best resolution in PFGE. However, PacI could be used only with some strains of C. limicola (8) because it has a high exonuclease activity, which makes it difficult to obtain restriction patterns for most strains. For the different strains the numbers of restriction fragments generated by $S w a I$ varied from 6 to 23 , and the fragment sizes ranged from 10 to $900 \mathrm{~kb}$ (Table 2).

The PFGE analysis of chromosomal DNAs digested with SwaI showed that there were clear differences in the restriction patterns of the various Chlorobium strains. The restriction pattern for $C$. limicola f. sp. thiosulfatophilum DSM 249 was identical to the pattern for $C$. limicola $\mathrm{f}$. sp. thiosulfatophilum BF8000 but different from the pattern for $C$. limicola $\mathrm{f}$. sp. thiosulfatophilum UdG6042. Interestingly, Chlorobium thiosulfatophilum UdG6038, which was assigned to the species $C$. limicola on the basis of phenotypic characteristics, had a restriction pattern identical to the pattern obtained for $C$. vibrioforme $\mathrm{f}$. sp. thiosulfatophilum DSM 263 and BF8200. Finally, all of the other strains had unique restriction patterns, and the big differences observed between strains assigned to the same species were remarkable.

Chromosome sizes for Chlorobium strains. The sizes of the chromosomes were estimated by adding the sizes of the individual fragment lengths in each restriction endonuclease digest. For each restriction analysis of a strain, the range of fragment sizes was subdivided into several classes, and band positions were determined from the gel with optimum resolution in each molecular weight class. The size of each DNA fragment was determined by calibration with linear DNA. Thus, the numbers of bands and chromosome sizes for all of the strains were compared when the enzyme SwaI was used. On the basis of the results obtained with $S w a I$ digests, the estimated sizes of the genomes of 15 Chlorobium strains ranged from $1,435.5 \mathrm{~kb}$ for $C$. chlorovibrioides UdG6026 to $3,342 \mathrm{~kb}$ for $C$. limicola BF 8010 (Table 2).

Chromosome sizes have been used successfully to differentiate bacterial strains (16). The sizes of the genomes of bacteria vary from $600 \mathrm{~kb}$ for Mycoplasma genitalium to $9,450 \mathrm{~kb}$ for Myxococcus xantus (2). The values obtained in this study place the chromosomes of Chlorobium strains around the intermediate size group of bacterial genomes (2). The size of the

TABLE 2. Sizes of chromosome SwaI restriction fragments of Chlorobium strains ${ }^{a}$

\begin{tabular}{|c|c|c|}
\hline Strain & Sizes of restriction fragments $(\mathrm{kb})$ & $\begin{array}{l}\text { Total } \\
(\mathrm{kb})\end{array}$ \\
\hline DSM $266^{\mathrm{T}}$ & $\begin{array}{l}385,335,270,242,195,155,140,120,105,90 \\
\quad 85,75,70,40\end{array}$ & 2,307 \\
\hline BF8600 & $\begin{array}{l}400,330,270,245,200,160,145,97,80,70 \\
\quad 60,50,40,20\end{array}$ & 2,172 \\
\hline BF8610 & $\begin{array}{l}480,440,340,291,275,224,195,180,137,123 \\
\quad 75,55,48,30,20\end{array}$ & 2,913 \\
\hline DSM 249 & $804,556,271,224,218,194,176,88,40,20,15$ & 2,616 \\
\hline BF8000 & $804,556,271,224,218,194,176,88,40,20,15$ & 2,616 \\
\hline UdG6042 & $\begin{array}{l}375,300,275,230,220,150,145,120,75,70 \\
\quad 65,55,55,48,45,35,30,25,20,17\end{array}$ & 2,355 \\
\hline DSM $245^{\mathrm{T}}$ & $\begin{array}{l}400,400,291,291,242,200,170,115,73,65 \\
\quad 60,50,45,40,17,15\end{array}$ & 2,414 \\
\hline BF8010 & $\begin{array}{l}436,388,380,340,271,240,224,206,190,170 \text {, } \\
\quad 145,135,120,97\end{array}$ & 3,342 \\
\hline UdG60401 & $\begin{array}{l}390,291,265,230,205,200,180,170,160,145 \\
121,116,97,48,48,40,35,30,30,25,20 \\
17,15\end{array}$ & 2,831 \\
\hline UdG6038 & $600,375,245,170,140,135,97,10$ & 2,112 \\
\hline DSM 263 & $600,375,245,170,140,135,97,10$ & 2,112 \\
\hline BF8200 & $600,375,245,170,140,135,97,10$ & 2,112 \\
\hline BF8210 & $915,450,388,295,280,215$ & 3,128 \\
\hline UdG6026 & $700,230,225,97,48.5,35,30$ & $1,435.5$ \\
\hline TLS $^{\mathrm{T}}$ & $436.5,339.5,280,260,200,160,145,75,17,12$ & 1,925 \\
\hline
\end{tabular}

\footnotetext{
${ }^{a}$ For complete names see Table 1.
} 
TABLE 3. Sizes of the rRNA hybridization bands of Chlorobium strains ${ }^{a}$

\begin{tabular}{ll}
\hline \multicolumn{1}{c}{ Strain } & \multicolumn{1}{c}{ Sizes of rRNA hybridization bands (bp) } \\
\hline DSM 266 & $11,000,9,500$ \\
BF8600 & $17,000,14,000,11,000,7,500,6,000,1,500$ \\
DSM 249 & $13,000,12,500,11,500,7,500,7,000,3,500,1,500$ \\
BF8000 & $13,000,12,500,11,500,7,500,7,000,1,500$ \\
UdG6042 & $12,750,12,000,6,900,6,000$ \\
DSM 245 & $11,500,8,000$ \\
BF8010 & $16,500,13,000,7,500,6,900,6,000,1,500$ \\
UdG6041 & $12,500,11,500,6,900,6,000,1,500$ \\
UdG6038 & $12,750,12,000,7,500,6,900,3,500$ \\
DSM 263 & $13,000,12,500,9,000,8,000$ \\
BF8200 & $13,000,12,500,9,000,8,000$ \\
BF8210 & $13,000,7,500,6,000,2,700,2,500,2,200$ \\
UdG6026 & $17,000,13,000,7,500,2,800,1,500$ \\
TLS & $12,500,12,000,10,500$ \\
\hline
\end{tabular}

\footnotetext{
${ }^{a}$ For complete names see Table 1.
}

chromosome of $C$. tepidum was estimated to be $2,150 \mathrm{~kb}(10)$ when the enzymes $P a c I$ and $X b a I$ were used, and this value is within the accepted range of size divergence with our estimate of $1,925 \mathrm{~kb}$ (around $10 \%$ divergence).

rRNA restriction patterns. A total of 14 Chlorobium strains were analyzed by ribotyping, and 13 restriction patterns were observed, although some of these patterns were nearly identical. The number of fragments that hybridized with the rRNA probe varied from two to seven for the different strains (Table 3). Ribotyping allowed us to distinguish some strains with identical PFGE macrorestriction patterns.

Concluding remarks. The results described above reveal that there is great genomic heterogeneity within the genus Chlorobium, both in chromosome material and in plasmid material. Thus, different strains contain different extrachromosomal elements, exhibit different chromosome macrorestriction patterns, and have different chromosome sizes. Moreover, ribotyping increased the level of discrimination among strains. In conclusion, it will be necessary to perform more molecular studies to clarify the real genetic relationships within this group of microorganisms.

We are grateful to Michael T. Madigan, Southern Illinois University, Carbondale, for providing C. tepidum TLS ${ }^{\mathrm{T}}$ and to the Department of Biology, University of Girona, for providing C. limicola UdG6026, UdG6038, UdG6041, and UdG6042 cultures. We thank J. Checa for technical assistance.

This work was supported by CICYT grant PB94-0730 to I.E. and by grant AMB 95-0516 to R.G. S.M. was supported by a scholarship from the Autonomous Government of Catalonia.

\section{REFERENCES}

1. Avissar, Y. J., and S. I. Beale. 1990. Cloning and expression of a structural gene from Chlorobium vibrioforme that complements the hemA mutation in
Escherichia coli. J. Bacteriol. 172:1656-1659.

2. Cole, S. T., and I. Saint Girons. 1994. Bacterial genomics. FEMS Microbiol. Rev. 14:139-160.

3. Gibson, J., W. Ludwig, E. Stackebrandt, and C. R. Woese. 1985. The phylogeny of the green photosynthetic bacteria: absence of a close relationship between Chlorobium and Chloroflexus. Syst. Appl. Microbiol. 6:152-156.

4. Guerrero, R., E. Montesinos, C. Pedrós-Alió, I. Esteve, J. Mas, H. van Gemerden, P. A. G. Hofman, and J. F. Bakker. 1985. Phototrophic sulfur bacteria in two Spanish lakes: vertical distribution and limiting factors. Limnol. Oceanogr. 30:919-931.

5. Kjaerulff, S., D. B. J. Diep, S. Okkels, H. V. Scheller, and J. G. Ormerod. 1994. Highly efficient integration of foreign DNA into the genome of the green sulfur bacterium Chlorobium vibrioforme by homologous recombination. Photosynth. Res. 41:277-283.

6. McClelland, M., M. Jones, Y. Patel, and M. Nelson. 1987. Restriction endonucleases for pulsed field mapping of bacterial genomes. Nucleic Acids Res. 15:5985-6005.

7. Méndez-Álvarez, S., V. Pavón, I., Esteve, R. Guerrero, and N. Gaju. 1994. Transformation of Chlorobium limicola by a plasmid that confers the ability to utilize thiosulfate. J. Bacteriol. 176:7395-7397.

8. Méndez-Álvarez, S., V. Pavón, I. Esteve, R. Guerrero, and N. Gaju. 1995. Genomic heterogeneity in Chlorobium limicola: chromosomic and plasmidic differences among strains. FEMS Microbiol. Lett. 134:279-285.

9. Nassar, A., Y. Bertheau, C. Dervin, J. Narcy, and M. Lemattre. 1994. Ribotyping of Eminia chrysanthemi strains in relation to their pathogenic and geographic distribution. Appl. Environ. Microbiol. 60:3781-3789.

10. Naterstad, K., A. Kolsto, and R. Sirevag. 1995. Physical map of the genome of the green phototrophic bacterium Chlorobium tepidum. J. Bacteriol 177: $5480-5484$.

11. Pfennig, N. 1989. Green sulfur bacteria, p. 1682-1709. In J. T. Staley, M. P. Bryant, N. Pfennig, and J. G. Holt (ed.), Bergey's manual of systematic bacteriology, vol. 3. Williams and Wilkins, Baltimore.

12. Pfennig, N., and H. G. Trüper. 1992. The family Chlorobiaceae, p. 3583-3592. In M. P. Starr, H. Stolp, H. G. Trüper, and H. G. Schlegel (ed.), The prokaryotes. Springer-Verlag, Berlin.

13. Pibernat, I. 1996. Ph.D. thesis. Universitat de Girona, Girona, Spain.

14. Rodrigo, A. G., K. M. Borges, and P. L. Bergquist. 1994. Pulsed-field gel electrophoresis of genomic digests of Thermus strains and its implications for taxonomic and evolutionary studies. Int. J. Syst. Bacteriol. 44:547-552.

15. Sambrook, J., E. F. Fritsch, and T. Maniatis. 1989. Molecular cloning: a laboratory manual, 2nd ed. Cold Spring Harbor Laboratory, Cold Spring Harbor, N.Y.

16. Sameeh, S. M., M. Garcia, and D. E. Taylor. 1992. Differentiation of the subspecies of Campylobacter fetus by genomic sizing. Int. J. Syst. Bacteriol. 42:446-450.

17. Schwartz, D. C., and C. R. Cantor. 1984. Separation of yeast chromosome sized DNAs by pulsed field gel gradient electrophoresis. Cell 37:67-75.

18. Smith, C. L., and C. R. Cantor. 1987. Purification, specific fragmentation and separation of large DNA molecules. Methods Enzymol. 155:449-467.

19. Smith, C. L., C. R. Klco, and C. R. Cantor. 1988. Pulsed field gel electrophoresis and the technology of large DNA molecules, p. 211-272. In K. E. Davies (ed.), Genome analysis. A practical approach. IRL, Oxford.

20. Van Gemerden, H., and H. H. Beeftink. 1983. Ecology of phototrophic bacteria, p. 146-185. In J. G. Ormerod (ed.), The phototrophic bacteria. Blackwell, Oxford.

21. Wahlund, T. M., and M. T. Madigan. 1995. Genetic transfer by conjugation in the thermophilic green sulfur bacterium Chlorobium tepidum. J. Bacteriol. 177:2583-2588.

22. Wahlund, T. M., C. R. Woese, R. W. Castenholz, and M. T. Madigan. 1991. A thermophilic green sulfur bacterium from New Zealand hot springs, Chlorobium tepidum sp. nov. Arch. Microbiol. 156:81-90. 